\title{
PENGARUH KEPUTUSAN INVESTASI, KEPUTUSAN PENDANAAN DAN KEBIJAKAN DEVIDEN TERHADAP NILAI PERUSAHAAN
}

\author{
Tania Ivanna A. Tanto ${ }^{1}$ \\ taniaatanto31@gmail.com \\ Aaron M. A. Simanjuntak, SE., M.Si, Ak, CBV, CMA ${ }^{2}$ \\ Bill J. C. Pangayow, SE., M.Si ${ }^{3}$ \\ Jurusan Akuntansi, Fakultas Ekonomi dan Bisnis Universitas Cenderawasih
}

\begin{abstract}
The value of the company is very important because the high value of the company will be followed by the high prosperity of shareholders. The higher the stock price, the higher the value of the company, in order to achieve company value, investors generally give their management to professionals. Optimizing company value can be achieved through the implementation of financial management functions, where one financial decision taken will influence other financial decisions and have an impact on the value of the company. This study aims to determine the effect of investment decisions, funding decision taken will influence other financial decision and have an impact on the value of the company. This study aims to determine the effect of investment decisions, funding decisions and dividend policies on firm value. The population in this study are all companies listed on the Indonesia Stock Exchange for the period 2014-2016 while sample selection using purposive sampling technique obtained 89 companies that will be used as samples in this study. The hypothesis testing uses multiple regression analysis. The results of the study partially show that investment decision affect the value of the company, funding decisions do not affect the value of the company and dividend policy does not affect the value of the company. While the simultaneous research result shows that investment decisions, funding decisions and dividend policies have a significant effect on firm value.
\end{abstract}

Keyword : investment decision, funding decision, dividend policies, firm value.

\section{PENDAHULUAN}

Manajemen keuangan memiliki tujuan yang ingin dicapai yaitu memaksimalkan nilai perusahaan. terdapat perbedaan yang dapat dilihat dari informasi antara investor dan kreditor sebagai pihak dari luar perusahaan dan manajer sebagai pihak dari dalam perusahaan. Pemegang saham akan sangat mengharapkan nilai saham yang maksimal agar manajer bertindak sesuai dengan kepentingan masing-masing melalui pengawasan yang dilakukan. Kreditur akan berusaha melindungi dana yang telah mereka investasikan dalam perusahaan dengan jaminan dan kebijakan dalam pengawasan yang ketat. Manajer memiliki dorongan dalam mengejar kepentingan pribadi, sehingga menimbulkan konflik yang sering disebut dengan konflik agensi. Brigham, E. F (2001) dalam Septia (2015) mengatakan, dalam mengurangi konflik perusahaan dengan cara mengalirkan sebagian kelebihan arus kas ke pemegang saham melalui dividen yang tinggi dan alternatif lainnya dengan penggunaan

\footnotetext{
${ }^{1}$ Alumni Jurusan Akuntansi FEB Uncen

${ }^{2}$ Dosen Jurusan Akuntansi FEB Uncen

3 Dosen Jurusan Akuntansi FEB Uncen
} 
hutang, dan diharapkan dengan hutang yang lebih tinggi dapat memaksa manajer menjadi lebih disiplin.

Manajemen keuangan juga menyangkut penyelesaian atas keputusan penting yang diambil perusahaan, antara lain keputusan investasi, keputusan pendanaan, dan kebijakan dividen. Perusahaan melakukan investasi dengan tujuan untuk mendapat keuntungan di masa yang akan datang. Keputusan investasi memiliki jangka waktu yang panjang, sehingga dalam mengambil keputusan harus dipertimbangkan dengan baik, karena memiliki risiko berjangka panjang pula. Suatu keputusan investasi dapat dipengaruhi oleh ketersediaan dana dalam perusahaan yang berasal dari sumber pendanaan internal maupun sumber pendanaan eksternal. Keputusan pendanaan berkaitan dengan struktur modal yang tepat bagi perusahaan.

Tujuan Keputusan pendanaan adalah dimana perusahaan menentukan sumber dana yang maksimal dalam mendanai berbagai alternatif investasi, sehingga dapat memaksimalkan nilai perusahaan yang tercermin pada harga sahamnya. Selain keputusan investasi dan keputusan pendanaan, kebijakan dividen juga merupakan suatu masalah yang sering dihadapi oleh perusahaan. Dividen juga merupakan alasan bagi investor dalam menanamkan investasinya, yang dimana dividen merupakan pengembalian yang akan diterimanya atas investasinya dalam suatu perusahaan.

Para investor memiliki tujuan utama yaitu untuk meningkatkan kesejahteraannya dengan mengharapkan pengembalian dalam bentuk dividen, sedangkan perusahaan mengharapkan pertumbuhan secara terus-menerus untuk mempertahankan kelangsungan hidupnya sekaligus memberikan kesejahteraan kepada para pemegang sahamnya. Kebijakan dividen penting untuk memenuhi harapan pemegang saham terhadap dividen dengan tidak menghambat tumbuh dan berkembangnya perusahaan disisi yang lainnya. Fama (1978) dalam Wijaya (2010) berpendapat bahwa optimalisasi nilai perusahaan dapat dicapai melalui pelaksanaan fungsi manajemen keuangan, dimana satu keputusan keuangan yang diambil akan mempengaruhi keputusan keuangan lainnya dan berdampak pada nilai perusahaan.

Manajemen keuangan menyangkut penyelesaian atas keputusan penting yang diambil perusahaan, antara lain keputusan investasi, keputusan pendanaan, dan kebijakan dividen. Suatu kombinasi yang optimal atas ketiganya akan memaksimumkan nilai perusahaan. Penelitian mengenai nilai perusahaan telah dilakukan oleh beberapa peneliti, diantaranya yaitu Ningsih dan Indarti (2009), Hasnawati (1998) dan Dimas Prasetyo et al (2012) menunjukan bahwa keputusan pendanaan berpengaruh positif dan signifikan terhadap nilai perusahaan. Sebaliknya, penelitian yang dilakukan oleh Oktaviana Tiara Sari (2013) menunjukkan bahwa keputusan pendanaan berpengaruh negatif tidak signifikan terhadap nilai perusahaan. Hal ini menunjukkan bahwa pengaruh keputusan pendanaan terhadap nilai perusahaan masih bervariasi.

Fama (1978) dalam Wijaya (2010) berpendapat bahwa optimalisasi nilai perusahaan dapat dicapai melalui pelaksanaan fungsi manajemen keuangan, dimana satu keputusan keuangan yang diambil akan mempengaruhi keputusan keuangan lainnya dan berdampak pada nilai perusahaan Manajemen keuangan menyangkut penyelesaian atas keputusan penting yang diambil perusahaan, antara lain keputusan investasi, keputusan pendanaan, dan kebijakan dividen. Suatu kombinasi yang optimal atas ketiganya akan memaksimumkan nilai perusahaan yang akan meningkatkan kemakmuran kekayaan pemegang saham. Hal ini menunjukkan bahwa faktor keputusan investasi, keputusan pendanaan dan kebijakan dividen dapat mempengaruhi nilai perusahaan.

Pada penelitian ini akan mengambil sample pada seluruh perusahaan yang terdaftar di Bursa Efek Indonesia dengan tahun pengamatan yaitu 2014-2016. Alasan penelitian ini dilakukan yaitu untuk mengakaji: 1). Apakah keputusan investasi berpengaruh terhadap nilai perusahaan ?, 2). Apakah keputusan pendanaan berpengaruh terhadap nilai perusahaan ?, dan 3). Apakah kebijakan dividen 
berpengaruh terhadap nilai perusahaan ?. Dengan tujuan penelitian yaitu: 1). Untuk menguji apakah keputusan investasi berpengaruh positif terhadap nilai perusahaan. 2). Untuk menguji apakah keputusan pendanaan berpengaruh positif terhadap nilai perusahaan. dan 3). Untuk menguji apakah kebijakan dividen berpengaruh positif terhadap niali perusahaan.

\section{TINJAUAN PUSTAKA}

\subsection{Teori Sinyal}

Teori sinyal adalah sinyal (tanda) yang diberikan oleh manajemen perusahaan kepada investor sebagai petunjuk mengenai prospek perusahaan (Brihgam dan Houston,2011:186). Teori sinyal menyatakan pengeluaran investasi memberikan sinyal positif tentang pertumbuhan perusahaan dimasa yang akan datang, sehingga meningkatkan harga saham sebagai indikator nilai perusahaan (Hasnawati, 2005). Sinyal ini berupa informasi mengenai penyajian keterangan, catatan, atau gambaran baik untuk keadaan masa lalu, saat ini maupun masa yang akan datang bagi kelangsungan hidup perusahaan dan bagaimana efeknya bagi perusahaan oleh manajemen untuk mewujudkan keingian pemilik. Peningkatan hutang diartikan oleh pihak luar sebagai kemampuan perusahaan untuk membayar kewajiban di masa yang akan datang atau adanya risiko bisnis yang rendah, hal tersebut akan direspon secara positif oleh pasar (Brigham, 1999).

Kebijakan dividen sering dianggap sebagai sinyal bagi investor dalam menilai baik buruknya perusahaan, hal ini disebabkan karena kebijakan dividen dapat membawa pengaruh terhadap harga saham perusahaan. Kenaikan jumlah dividen dianggap sebagai sinyal bahwa manajemen perusahaan meramalkan laba yang baik di masa depan Brigham dan Houston (2011). Penggunaan dividen sebagai isyarat berupa pengumuman yang menyatakan bahwa suatu perusahaan telah memutuskan untuk menaikkan dividen perlembar saham mungkin diartikan oleh penanam modal sebagai sinyal yang baik, karena dividen per saham yang lebih tinggi menujukkan bahwa perusahaan yakin arus kas masa mendatang akan cukup besar untuk menanggung tingkat dividen yang tinggi Weston dan Copeland (1997).

\subsection{Nilai Perusahaan}

Nilai perusahaan atau juga disebut dengan nilai pasar perusahaan merupakan harga yang bersedia dibayar oleh calon pembeli apabila perusahaan tersebut dijual. Fakta menunjukkan bahwa nilai kekayaan yang ditunjukkan pada neraca tidak memiliki hubungan dengan nilai pasar dari perusahaan. Hal ini disebabkan karena perusahaan memiliki kekayaan yang tidak bisa dilaporkan dalam neraca seperti manajemen yang baik, reputasi yang baik dan prospek yang cerah Erlangga dan Suryandari (2009). Nilai perusahaan juga didefinisikan sebagai nilai pasar karena nilai perusahaan dapat memberikan kemakmuran pemegang saham secara maksimum apabila harga saham perusahaan meningkat Hasnawati (2005) dalam Wijaya dan Wibawa(2010).

Menurut Harmono (2009:50) nilai perusahaan dapat diukur melalui nilai harga saham di pasar, berdasarkan terbentuknya harga saham perusahaan di pasar, yang merupakan refleksi penilaian oleh publik terhadap kinerja perusahaan secara riil. Dikatakan secara riil karena terbentuknya harga saham di pasar merupakan titik bertemunya kesepakatan antara permintaan dan penawaran harga yang secara riil terjadi transaksi jual beli surat berharga di pasar modal antara emiten dan para investor. Menurut Harmono (2009:233) nilai perusahaan adalah kinerja perusahaan yang dicerminkan oleh harga saham yang dibentuk oleh permintaan dan penawaran di pasar modal yang merefleksikan penilaian masyarakat terhadap kinerja perusahaan. Nilai perusahaan juga dapat didefinisikan sebagai alat pasar karena nilai perusahaan dapat memberikan kesejahteraan pemegang saham secara maksimum apabila harga saham perusahaan meningkat. Nilai perusahaan juga bisa dikatakan nilai 
pasar perusahaan karena apabila perusahaan tersebut di jual calon pembeli bersedia untuk membeli perusahaan tersebut dengan harga berapapun (I Made Sudana 2011:7).

\subsection{Keputusan Investasi}

Keputusan investasi adalah salah satu keputusan yang harus diambil manajer keuangan untuk mengalokasikan dana-dana yang ada agar mendatangkan keuntungan di masa mendatang. Investasi berasal dari dalam maupun luar perusahaan. Investasi yang berasal dari dalam perusahaan meliputi kas, surat-surat berharga, piutang dagang, persediaan, dll. Investasi ini terletak dalam aset lancar di laporan neraca perusahaan. Kemudian investasi dari luar perusahaan meliputi peralatan, tanah, gedung, mesin, kendaraan, dll. Investasi ini terletak dalam aset tetap di laporan neraca. Keputusan investasi terletak di sisi kiri laporan neraca. Dalam setiap kasus perusahaan menanamkan sejumlah uang sekarang dengan harapan menerima uang yang lebih banyak nanti.

\subsection{Keputusan Pendanaan}

Keputusan pendanaan adalah keputusan selanjutnya yang harus diambil manajer keuangan untuk mendanai investasi yang dilakukan perusahaan. Pada keputusan ini, manajer keuangan harus mempertimbangkan dan menganalisis sumber-sumber dana untuk membiayai investasi tersebut. keputusan manajer keuangan ini harus memahami betul berapa proporsi, komposisi, kombinasi, dan efisiensi pembiayaan yang diperlukan perusahaan. Keputusan ini terletak pada sisi kanan laporan neraca berupa kewajiban lancar dan kewajiban jangka panjang.

Keputusan pendanaan merupakan keputusan yang menyangkut komposisi pendanaan yang dipilih perusahaan Murtini (2008:40). Semakin tinggi rasio dapat menunjukkan buruknya keadaan keuangan perusahaan karena tingginya resiko keuangan yang akan ditanggung oleh perusahaan. Hal ini menyebabkan besarnya proporsi dana yang berasal dari hutang. Jadi semakin besar rasio hutang dan rasio aset atau rasio hutang dengan ekuitas, berarti makin besar resiko keuangan perusahaan, karena resiko ketidakmampuan perusahaan untuk memenuhi beban tetap berupa bunga ataupun pelunasan hutang pokoknya dalam situasi perekonomian yang memburuk Halim(2007:159).

Keputusan pendanaan dan investasi (baik jangka panjang maupun jangka pendek) tentu saja saling terkait. Jumlah investasi menentukan jumlah pendanaan yang harus diperoleh, dan para investor yang berkontribusi mendanai saat ini mengharapkan pengembalian investasi di masa depan. Oleh sebab itu, investasi yang dilakukan perusahaan harus menghasilkan pengembalian di masa depan untuk dibayarkan kepada para investor Brealey, Myers, dan Marcus (2008:7).

\subsection{Kebijakan Deviden}

Dividen merupakan pembayaran dari perusahaan kepada para pemegang saham atas keuntungan yang diperolehnya. Kebijakan dividen adalah kebijakan yang berhubungan dengan pembayaran dividen oleh pihak perusahaan, berupa penentuan besarnya dividen yang dibagikan dan besarnya saldo laba yang ditahan untuk kepentingan perusahaan Sutrisno(2001). Menurut Hin (2001) dividen adalah pembagian bagian keuntungan kepada para pemegang saham. Besarnya dividen yang dibagikan perusahaan ditentukan oleh para pemegang saham pada saat berlangsungnya RUPS (Rapat Umum Pemegang Saham).

Perusahaan yang memilih kebijakan dividen tinggi tanpa arus kas untuk mendukungnya, pada akhirnya harus memotong investasi atau beralih ke pasar modal untuk mendapatkan pendanaan utang atau ekuitas tambahan. Karena mahal, manajer tidak meningkatkan dividen kecuali mereka yakin bahwa perusahaan menghasilkan cukup banyak kas untuk membayar mereka. Ini adalah alasan utama yang kita katakan bahwa ada isi informasi dividen-yaitu, perubahan dividen dapat diterjemahkan sebagai tanda perubahan prospek perusahaan Brealey, Myers, Marcus,( 2008:60). 
Apabila perusahaan memilih untuk menahan laba yang diperoleh, maka kemampuan pembentukan dana internal akan semakin besar, apabila perusahaan penerbit saham mampu menghasilkan laba yang besar kemungkinan pemegang sahamnya akan menikmati keuntungan dalam bentuk dividen yang besar pula. Sebaliknya jika perusahaan memilih untuk membagikan laba sebagai dividen, maka akan mengurangi laba yang ditahan dan mengurangi total sumber dana internal financing. Sartono dalam Putri Prihatin Ningsih (2001:281).

\subsection{Penelitian Terdahulu dan Pengembangan Hipotesis \\ 2.6.1 Pengaruh Keputusan Investasi Terhadap Nilai Perusahaan}

Menurut Wahyudi dan Pawestri (2006), nilai perusahaan yang dibentuk melalui indikator nilai pasar saham sangat dipengaruhi oleh peluang-peluang investasi. Nilai perusahaan semata-mata ditentukan oleh keputusan investasi. Pernyataan sesuai hasil penelitian Fama dan French (1998) menemukan bahwa investasi yang dihasilkan dari kebijakan dividen dan leverage memiliki informasi yang positif tentang perusahaan di masa yang akan datang selanjutnya berdampak positif terhadap nilai perusahaan.

Sementara itu penelitian Wijaya dan Wibawa (2010) dapat memberikan konfirmasi empiris bahwa keputusan investasi berpengaruh positif terhadap nilai perusahaan. Hasil yang serupa dapat diketahui pada penelitian Hasnawati (2005) yang menemukan bukti empiris bahwa keputusan investasi berpengaruh positif terhadap nilai perusahaan sebesar $12,25 \%$, sedangkan sisanya sebesar $87,75 \%$ dipengaruhi oleh faktor lain seperti keputusan pendanaan, kebijakan dividen, faktor eksternal perusahaan seperti: tingkat inflasi, kurs mata uang, pertumbuhan ekonomi, politik, dan psikologi pasar. Dan menurut Wahyudi dan Pawestri (2006) menemukan bahwa keputusan investasi tidak berpengaruh terhadap nilai perusahaan.

Teori sinyal menjelaskan bahwa pengeluaran investasi memberikan sinyal positif tentang pertumbuhan perusahaan dimasa yang akan datang, sehingga meningkatkan harga saham sebagai indikator nilai perusahaan. Keputusan investasi dalam penelitian ini diproksikan dengan Price Earnings Ratio (PER). PER yang tinggi menunjukkan investasi perusahaan yang bagus dan prospek pertumbuhan perusahaan yang bagus sehingga para investor akan tertarik. Permintaan saham yang tinggi akan membuat para investor menghargai nilai saham lebih besar dari pada nilai yang tercatat pada neraca perusahaan, sehingga PBV perusahaan tinggi dan nilai perusahaan pun tinggi. Dengan demikian maka keputusan investasi memiliki pengaruh positif terhadap nilai perusahaan.

\section{H1: Keputusan investasi berpengaruh positif terhadap nilai perusahaan}

\subsubsection{Pengaruh Keputusan Pendanaan Terhadap Nilai Perusahaan}

Menurut Brigham dan Houston (2001) dalam Wijaya dan Wibawa (2010), menyatakan bahwa peningkatan hutang diartikan oleh pihak luar tentang kemampuan perusahaan untuk membayar kewajiban di masa yang akan datang atau adanya risiko bisnis yang rendah, hal tersebut akan direspon secara positif oleh pasar. Terdapat dua pandangan mengenai keputusan pendanaan. Pandangan pertama dikenal dengan pandangan tradisional yang menyatakan bahwa struktur modal mempengaruhi nilai perusahaan. Peningkatan pendanaan melalui utang merupakan salah satu alternatif untuk mengurangi biaya keagenan. Hutang dapat mengendalikan manajer untuk mengurangi tindakan perquisites dan kinerja perusahaan menjadi lebih efisien sehingga penilaian investor terhadap perusahaan akan meningkat. Arieska dan Gunawan (2011).

Penelitian Wijaya dan Wibawa (2010), Wahyudi dan Pawestri (2006) dan Hasnawati (2005) sama-sama menemukan bukti bahwa keputusan pendanaan mempengaruhi nilai perusahaan secara 
positif. Manajer dapat menggunakan hutang sebagai sinyal yang lebih terpercaya untuk para investor. Ini karena perusahaan yang meningkatkan hutang dapat dipandang sebagai perusahaan yang yakin dengan prospek perusahaan di masa yang akan datang. Jadi penggunaan hutang merupakan tanda atau sinyal positif dari perusahaan yang dapat membuat para investor menghargai nilai saham lebih besar dari pada nilai yang tercatat pada neraca perusahaan, sehingga PBV perusahaan tinggi dan nilai perusahaan pun tinggi. meningkatkan nilai perusahaan. Dengan demikian maka keputusan pendanaan memiliki pengaruh positif terhadap nilai perusahaan.

\section{H2: Keputusan pendanaan berpengaruh positif terhadap nilai perusahaan}

\subsubsection{Pengaruh Kebijakan Dividen Terhadap Nilai Perusahaan}

Pada dasarnya, laba bersih perusahaan bisa dibagian kepada pemegang saham sebagai dividen atau ditahan dalam bentuk laba ditahan untuk membiayai investasi perusahaan. Kebijakan dividen menyangkut keputusan tentang penggunaan laba yang menjadi hak pemegang saham. Menurut Hatta (2002) dalam Wijaya dan Wibawa (2010), terdapat sejumlah perdebatan mengenai bagaimana kebijakan deviden mempengaruhi nilai perusahaan. Pendapat pertama menyatakan bahwa kebijakan dividen tidak mempengaruhi nilai perusahaan, yang disebut dengan teori irrelevansi dividen. Pendapat kedua menyatakan bahwa dividen yang tinggi akan meningkatkan nilai perusahaan, yang disebut dengan Bird in The Hand Theory. Pendapat ketiga menyatakan bahwa semakin tinggi dividend payout ratio suatu perusahaan, maka nilai perusahaan tersebut akan semakin rendah.

Penelitian Wijaya dan Wibawa (2010), dapat membuktikan bahwa kebijakan dividen mempengaruhi nilai perusahaan secara positif. Perusahaan yang dapat memberikan dividen tinggi juga akan mendapatkan nilai kepercayaan yang tinggi dari para investor, karena investor lebih menyukai kepastian tentang returns investasinya dan mengantisipasi risiko ketidakpastian tentang kebangkrutan perusahaan. Dividen yang tinggi akan membuat para investor tertarik sehingga meningkatkan permintaan saham. Permintaan saham yang tinggi akan membuat para investor menghargai nilai saham lebih besar dari pada nilai yang tercatat pada neraca perusahaan, sehingga PBV perusahaan tinggi dan nilai perusahaan pun tinggi. Dengan demikian maka kebijakan dividen memiliki pengaruh positif terhadap nilai perusahaan.

\section{H3: Kebijakan dividen berpengaruh positif terhadap nilai perusahaan}

\subsection{Model Penelitian}

Berdasarkan teori dan jurnal-jurnal pendukung maka didapatkan model penelitian sebagai berikut dimana Keputusan investasi yang dilakukan perusahaan dapat mempengaruhi nilai perusahaan begitu pula keputusan pendanaan dan kebijakan dividen. Dalam kerangka pemikiran tersebut menggambarkan tindakan yang dilakukan perusahaan akan merespon pasar dan meningkatkan nilai perusahaan. 


\section{Gambar 1}

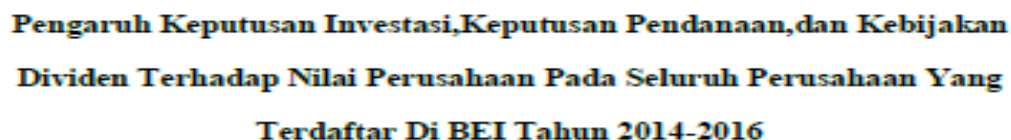

Terdaftar Di BEI Tahun 2014-2016

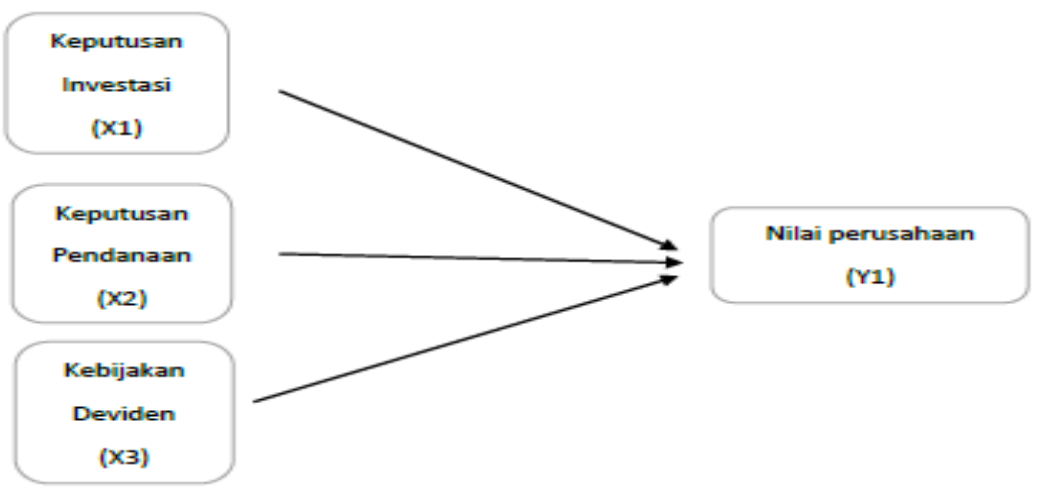

Sumber: dikembangkan oleh penulis (2018)

\section{METODE PENELITIAN}

\subsection{Jenis dan Sumber Data}

Jenis data yang dapat digunakan dalam penelitian ini adalah data sekunder. Dimana Data sekunder adalah data-data yang telah tersedia, dan selanjutnya dilakukan proses analisis dan interpretasi terhadap data-data tersebut sesuai dengan tujuan penelitian. Sumber data yang digunakan berasal dari laporan keuangan perusahaan sampel yang terdapat didalam, Bursa Efek Indonesia dan. Data yang diambil ialah harga saham, nilai buku, harga penutupan lembar saham, total hutang, total ekuitas, dividen per saham.

\subsection{Populasi dan Sampel Penelitian}

Populasi merupakan sekelompok orang, kejadian atau segala sesuatu yang menjadi perhatian dari peneliti untuk diselidiki (Sekarang, 2018). Populasi pada penelitian ini ialah seluruh perusahaan yang terdaftar dalam Bursa Efek Indonesia (BEI). Sampel merupakan bagian dari populasi yang digunakan sebagai objek penelitian. Dalam penelitian ini, sampel dapat ditentukan dengan menggunakan metode purposive sampling. Dimana Metode sampling tersebut membatasi pemilihan sampel berdasarkan kriteria tertentu. Adapun kriteria perusahaan yang dijadikan sampel dalam penelitian ini antara lain :

1. Seluruh perusahaan yang terdaftar di BEI dan mempublikasikan laporan keuangan secara berturut-turut selama periode 2014-2016

2. Perusahaan yang membagikan dividen selama periode penelitian.Periode penelitian ini selama tahun 2014-2016

3. Perusahaan yang di nyatakan dalam bentuk rupiah selama periode 2014 - 2016 


\subsection{Teknik Pengumpulan Data}

Teknik yang digunakan dalam penelitian ini adalah metode dokumentasi, dimana metode ini dilakukan dengan cara mengumpulkan literature yang memiliki sebagai kriteria dalam penyusunan penelitian, dimana pengumpulan data yang dilakukan didapat dari data yang sudah dikumpulkan dan diolah pihak lain.

\subsection{Variabel Penelitian dan Definisi Operasional \\ 3.4.1 Variabel Dependen}

Variabel dependen dalam penelitian ini adalah nilai perusahaan, dimana nilai perusahaan didefinisikan sebagai nilai pasar karena nilai perusahaan dapat memberikan kemakmuran pemegang saham secara maksimum apabila harga saham perusahaan meningkat (Hasnawati, 2005 dalam Wijaya dan Wibawa, 2010). Nilai perusahaan dalam penelitian ini diproksikan dengan Price Book Value (PBV). PBV mengukur nilai yang diberikan pasar keuangan kepada manajemen dan organisasi perusahaan sebagai sebuah perusahaan yang terus tumbuh. PBV dirumuskan dengan :

Prace book value $=\underline{\text { Harga saham }}$

Book Value

\subsubsection{Variabel Independen}

1. Keputusan Investasi

Keputusan investasi yang didefinisikan sebagai kombinasi antara aktiva yang dimiliki (assets in place) dan pilihan investasi di masa yang akan datang dengan net present value positif (Myers, 1977 dalam Wijaya dan Wibawa, 2010). Keputusan investasi dalam penelitian ini diproksikan dengan PER (Price Earning Ratio), dimana PER menunjukkan perbandingan antara closing price dengan laba per lembar saham (earning per share). PER dirumuskan dengan :

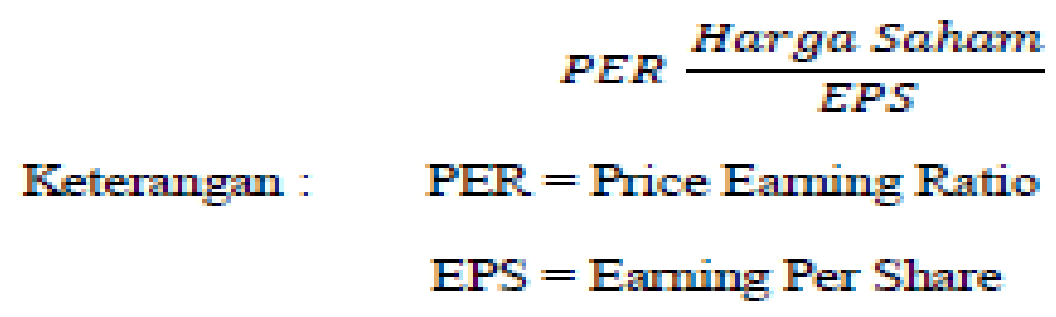

\section{Keputusan Pendanaan}

Keputusan pendanaan didefinisikan sebagai keputusan yang menyangkut komposisi pendanaan yang dipilih oleh perusahaan Hasnawati, (2005) dalam Wijaya dan Wibawa, (2010). Keputusan pendanaan dalam penelitian ini diproksikan dengan Debt to Equity Ratio (DER), dimana rasio ini menunjukkan perbandingan antara pembiayaan dan pendanaan melalui hutang dengan pendanaan melalui ekuitas. DER dirumuskan dengan :

$$
D E R=\frac{\text { Total Hutang }}{\text { Total Ekuitas }}
$$




\section{Kebijakan Deviden}

Keputusan kebijakan dividen adalah keputusan tentang seberapa banyak laba saat ini yang akan dibayarkan sebagai dividen daripada ditahan untuk diinvestasikan kembali dalam perusahaan Brigham dan Houston, (2001) dalam Wijaya dan Wibawa (2010). Kebijakan dividen dalam penelitian ini diproksikan dengan Dividend Payout Ratio (DPR), dimana rasio pembayaran dividen adalah persentase laba yang dibayarkan kepada para pemegang saham dalam bentuk kas. DPR dirumuskan dengan :

$$
\text { DPR } \frac{\text { DPS }}{\text { EPS }}
$$

Keteramgan :

DPR $=$ Dividend Payount Ratio

DPS = Dividen Pler Share

EPS: = Earning Per Share

\subsection{Metode Analisis Data}

Metode analisis yang digunakan dalam penelitian ini adalah analisis regresi berganda. Analisis regresi berganda digunakan untuk menguji pengaruh antara nilai perusahaan dengan variabel bebas (independen).

\subsubsection{Analisis Statistik Deskriptif}

Analisis statistik deskriptif ditujukan untuk melihat profil dari penelitian tersebut dan memberikan gambaran terhadap objek yang diteliti melalui data sampel dan membuat kesimpulan yang berlaku umum. Statistik deskriptif digunakan untuk mendiskripsikan suatu data yang dilihat dati mean, median, deviasi standar, nilai minimum, dan nilai maksimum (Ghozali, 2007). Pengujian ini dilakukan untuk mempermudah memahami variabel-variabel yang digunakan dalam penelitian.

\subsubsection{Pengujian Hipotesis}

\section{Metode Regresi Linier Berganda}

Pengujian hipotesis digunakan untuk mengetahui kekuatan variabel independen terhadap variabel dependen (Sekaran, 2006). Hubungan antar variable dapat digambarkan dengan persamaan sebagai berikut:

$\mathbf{Y}=\boldsymbol{\alpha}+\boldsymbol{\beta 1 K I}+\boldsymbol{\beta 2 K P}+\beta 3 \mathrm{KD}+\mathbf{e}$

Dimana:

$\mathrm{Y}=$ Nilai Perusahaan

$\mathrm{A}=$ Konstanta

$\mathrm{B}=$ Slope atau Koefisien Regresi

$\mathrm{KI}=$ Kebijakan Investasi

$\mathrm{KP}=$ Kebijakan Pendanaan

$\mathrm{KD}=$ Kebijakan Dividen 


\section{HASIL PENELITIAN DAN PEMBAHASAN}

\subsection{Statistik Deskriptif}

Populasi yang digunakan dalam penelitian ini adalah seluruh perusahaan yang terdaftar di Bursa Efek Indonesia (BEI) tahun 2014-2016. Penelitian ini menguji pengeruh keputusan investasi yang diproksikan dengan Price Earning Ratio (PER),keputusan pendanaan diproksikan dengan Debt to Equity Ratio (DER), dan kebijakan dividen diproksikan dengan menggunakan Deviden Payout Ratio (DPR). pengambilan sampel perusahaan dalam penelitian ini menggunakan teknik proposive sampling,yaitu teknik pengambilan data dengan pertimbangan kriteria tertentu.

Kriteria perusahaan yang dijadikan sampel daalm penelitian ini adalah :

1. Seluruh perusahaan yang terdaftar di BEI dan mempublikasikan laporan keuangan secara berturutturut selama periode 2014-2016

2. Perusahaan yang membagikan dividen selama periode penelitian.Periode penelitian ini selama tahun 2014-2016

3. Perusahaan yang di nyatakan dalam bentuk rupiah selama periode

$2014-2016$

Berdasarkan kriteria tersebut maka terdapat 89 perusahaan yang terpilih dari seluruh perusahaan yang terdaftar di BEI yang datanya sesuai dengan kriteria yang telah ditentukan. Berikut ini gambaran statistic deskriptif untuk masing-masing variabel.

\section{Tabel 1}

Statistik Deskriptif Variabel

\begin{tabular}{|c|c|c|c|c|c|}
\hline \multicolumn{6}{|c|}{ Descriptive Statistics } \\
\hline & $\mathrm{N}$ & Minimum & Maximum & Mean & Std Deviation \\
\hline $\begin{array}{ll}\text { Price } & \text { Eaming } \\
\text { Ratio } & \end{array}$ & 267 & -1096.096 & 24691.753 & 368.18982 & 2625.604447 \\
\hline Pendanaan & 267 & .021 & 11.523 & 1.83130 & 2.201556 \\
\hline $\begin{array}{l}\text { Dividen } \\
\text { Ratio }\end{array}$ & 267 & -4.263 & 150.909 & 1.05133 & 9.372737 \\
\hline Price Book Value & 267 & .000 & 4050.172 & 50.81036 & 389.978566 \\
\hline Valid N (listwise) & 267 & & & & \\
\hline
\end{tabular}

Tujuan dari hasil uji statistic deskriptif adalah untuk melihat kualitas data penelitian yang ditunjukan dengan angka atau nilai yang terdapat pada mean, dan standar deviasi dapat dikatakan apa bila mean lebih besar dari pada standar deviasi atau menyimpang maka kualitas data lebih baik . Berdasarkan hasil tabel 1 diatas dapat diketahui bahwa data yang dianalisis berjumlah 267 data. Selama periode 2014 sampai dengan 2016 dapat diketahui nilai minimum keputusan investasi (price earning ratio )- 1096.096, maximum 24691.75, rata-rata 368.18982 dan standar deviasi sebesar 2625.604447. Hasil analisis menggunakan perhitungan keputusan pendanaan (debt to equty ratio ) memiliki nilai minimum 0,021, maximum 0,021, rata-rata 11.523 dan nilai standar diviasi 2.201556. Kebijakan Dividen (dividen payout ratio) menunjukan hasil miminum sebesar -4.263,maximum 150.909, rata-rata 1.05133 dan nilai standar diviasi 9.372737. Sedangkan pada nilai perusahaan ( price book value) nilai minimum 0.000,maximum 4050.172 ,rata -rata 50.81036 danpada nilai standar diviasi sebesar 389.978566. 


\subsection{Hasil Pengujian Hipotesis}

\section{Hasil Analisis Regresi Berganda}

Dalam penelitian ini menggunakan analisis regresi berganda dimana analisis Regresi adalah analisis yang mengukur pengaruh variabel bebas terhadap variabel terikat. Pengukuran pengaruh ini melibatkan satu variabel bebas (X) dan variabel terikat (Y) untuk melihat pengaruh dari variabel independen dalam penelitian ini yang terdiri dari Price Earning Ratio (PER), Debt to Equity Ratio (DER), dan Deviden Payout Ratio (DPR) terhadap variabel dependen price book value .berikut ini merupakan tabel 2 yang menyajikan hasil analisi regresi berganda.

\section{Tabel 2}

Hasil Analisis Regresi Linear Berganda

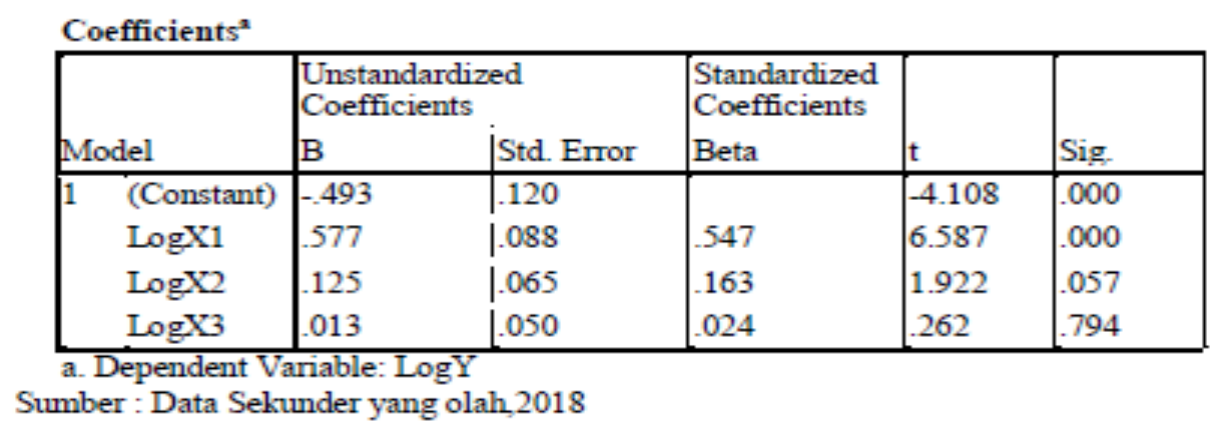

Berdasarkan hasil analisi regresi berganda tersebut,dapat diketahui bahwa nilai konstanta (a) dari model regres yang digunakan sebesar -493 dari setiap variabel independen sebesar $\mathrm{KI}=0,577, \mathrm{KP}$ $=0,125$ dan $\mathrm{KD}=0,013$ dengan menggunakan hasil dari analisis regresi linear berganda tersebut, maka hubungan antara variabel independen terhadap variabel dependen menggunakan rumus : $\mathrm{Y}=-493+0,577+0,125+0,013+\mathrm{e}$

\section{Hasil Uji Parsial (Uji t)}

Menurut Imam Ghozali (2006) uji statistik t pada dasarnya menunjukkan seberapa jauh pengaruh satu variabel independen secara individual dalam menerangkan variabel dependen. Pengujian dilakukan dengan menggunakan signifikan level 0,05 ( $\alpha=5 \%)$. Penerimaan atau penolakan hipotesis dilakukan dengan kriteria:

1. Jika nilai signifikan $>0,05$ maka hipotesis ditolak (koefisien regresi tidak signifikan). Ini berarti secara parsial variabel independen tidak mempunyai pengaruh secara signifikan terhadap variabel dependen.

2. Jika nilai signifikan $\leq 0,05$ maka hipotesis diterima (koefisien regresi signifikan). Ini berarti secara parsial variabel independen tersebut mempunyai pengaruh yang signifikan terhadap variabel dependen.

Berdasarkan pada hasil yang telah didapat, maka dapat diketahui bahwa keputusan investasi berpengaruh signifikan pada tingkat signifikan 0.05 dengan nilai signifikan sebesar 0,00 . Berdasarkan pada hasil pengujian parsial ini,maka dapat diinterpretasikan bahwa keputusan investasi berpengaruh pada nilai perusahaan. Dan, keputusan pendanaan tidak berpengaruh terhadap Nilai Perusahaan pada tinggkat signifikan 0,05 dengan nilai signifikan 0,057 sehingga hasil tersebut dapat dikatakan bahwa Keputusaan Pendanaan tidak berpengaruh terhadap nilai perusahaan. Sedangkan, kebijakan dividen tidak berpengaruh terhadap nilai perusahaan hal ini dikarenaka tingkat signifikan 0,05 dengan nilai sebesar 0,794 hasil ini menjukan bahwa kebijakan dividen tidak berpengaruh terhadap nilai perusahaan. 


\section{Hasil Uji Simultan (Uji F)}

Uji F dikenal dengan Uji serentak atau uji anova, yaitu uji untuk melihat bagaimanakah pengaruh semua variabel bebasnya secara bersama-sama terhadap variabel terikatnya.untuk mengetahui apakah semua variabel bebas yang dimasukan dalam model mempunyai pengaruh secara simultan terhadap variabel terikat atau dependen.

\section{Tabel 3}

Hasil Uji Simultan

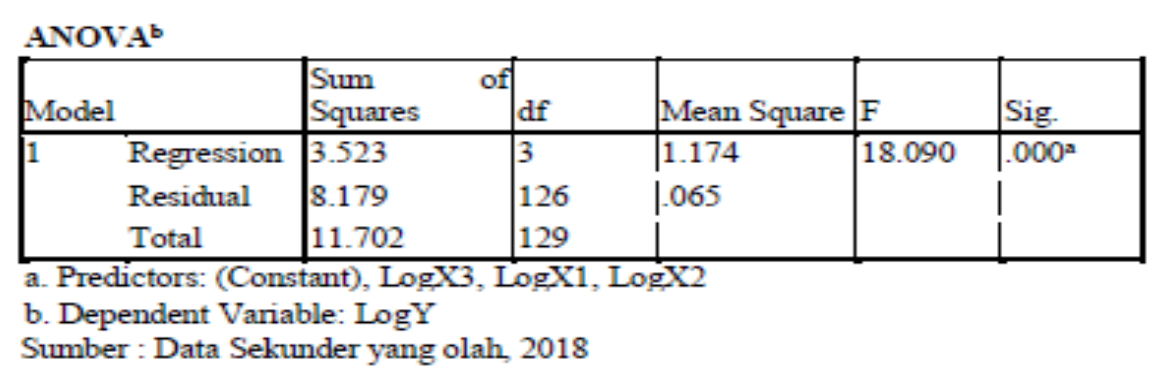

Berdasarkan hasil uji F didapat Fhitung sebesar 18,090 dengan tingkat signifikan 0,000 lebih kecil dibandingkan tingkat signifikan 0,05 sehingga dapat disimpulkan bahwa keputusan investasi,keputusan pendanaan dan kebijakan dividen mempunyai pengaruh secara simultan terhadapnilai perusahaan. Hal ini berarti variabel tersebut dapat dijadikan sebagai pengukur nilai perusahaan.

\section{Hasil Uji Koefisien Determinasi}

Dalam uji linear berganda, Koefisien determinasi digunakan untuk mengetahui prosentase sumbangan pengaruh serentak variabel-variabel bebas terhadap variabel terikat untuk itu digunakan angka-angka pada tabel model summary. Koefisien determinasi pada intinya mengukur seberapa besar kemampuan model dalam menerangkan variasi variabel dependen. Nilai R2 yang mendekati 1 dapat menunjukan bahwa variabel-variabel independen yang digunakan dalam penelitian ini mampu memberikan informasi yang dibutuhkan dalam memprediksi variasi dari variabel dependen (Ghozali,2006) . Pada tabel 4 dapat menunjukan hasil pengujian koefisien determinasi :

Tabel 4

Hasil Uji Koefisien Determinasi

\begin{tabular}{|c|c|c|c|c|c|}
\hline Mode & $R$ & R Square & $\begin{array}{l}\text { Adjusted R } \\
\text { Square }\end{array}$ & $\begin{array}{l}\text { Std. Error of } \\
\text { the Estimate }\end{array}$ & $\begin{array}{l}\text { Durbin- } \\
\text { Watson }\end{array}$ \\
\hline 1 & $549^{a}$ & 301 & 284 & 25479 & 1.766 \\
\hline
\end{tabular}

Berdasarkan pada tabel 4 bahwa 28,4\% yang diukur dengan price book value dapat dijelasakan oleh keputusan investasi,keputusan pendanaan dan kebijakan dividen secara bersama-sama sedangkan sisanya $72 \%$ dipengaruhi oleh factor-faktor yang tidak diteliti oleh peneliti. 


\subsection{Pembahasan}

\subsubsection{Pengaruh Keputusan Investasi Terhadap Nilai Perusahaan}

Berdasarkan pada hasil yang telah di uji maka keputusan investasi berpengaruh signifikan pada tingkat 0,05 dengan nilai signifikan 0,00 maka dapat disimpulkan bahwa hipotesis pertama di terima

Dalam hal ini adanya pengaruh keputusan investasi terhadap nilai perusahaan menunjukkan bahwa, jika manajer berhasil menciptakan keputusan investasi yang tepat maka aset yang diinvestasikan akan menghasilkan kinerja yang optimal sehingga memberikan suatu sinyal positif kepada investor yang nantinya akan meningkatkan harga saham dan nilai perusahaan. Investasi yang tinggi yang dilakukan perusahaan, maka akan meningkatkan nilai perusahaan. Investasi yang tinggi merupakan sinyal pertumbuhan pendapatan perusahaan di masa yang akan datang. Sinyal tersebut akan dianggap sebagai good news yang nantinya akan mempengaruhi persepsi investor terhadap kinerja perusahaan yang akhirnya akan mempengaruhi nilai perusahaan. Oleh karena itu, manajer harus menjaga perkembangan investasi sehingga dapat mencapai tujuan perusahaan melalui kesejahteraan pemegang saham dan dapat meningkatkan nilai perusahaan. Dan jika investasi perusahaan bagus maka akan berpengaruh pada kinerja perusahaan. Semakin positif PER menandakan semakin bagus investasi yang dimiliki oleh perusahaan. Perusahaan yang memiliki PER positif akan direspon positif oleh para investor dengan membeli saham tersebut sehingga akan menaikkan nilai perusahaan.

Hasil penelitian ini membenarkan teori signalling teory yang menjelaskan bahwa pengeluaran investasi memberikan sinyal positif tentang pertumbuhan perusahaan dimasa yang akan datang, sehingga meningkatkan harga saham sebagai indikator nilai perusahaan. Keputusan investasi dalam penelitian ini diproksikan dengan Price Earnings Ratio (PER). PER yang tinggi menunjukkan investasi perusahaan yang bagus dan prospek pertumbuhan perusahaan yang bagus sehingga para investor akan tertarik. Permintaan saham yang tinggi akan membuat para investor menghargai nilai saham lebih besar dari pada nilai yang tercatat pada neraca perusahaan, sehingga PBV perusahaan tinggi dan nilai perusahaan pun tinggi. Dengan demikian maka keputusan investasi memiliki pengaruh positif terhadap nilai perusahaan.

Hasil penelitian ini konsisten dengan penelitian yang dilakukan oleh Wijaya (2010) yang memproksikan keputusan investasi dengan Price Earning Ratio (PER) dan mengatakan bahwa efek langsung keputusan investasi terhadap nilai perusahaan merupakan hasil yang diperoleh dari kegiatan investasi itu sendiri melalui pemilihan proyek atau kebijakan lainnya seperti menciptakan produk baru, penggantian mesin yang lebih efisien. Pengeluaran modal perusahaan (capital expenditure) sangat penting untuk meningkatkan nilai perusahaan karena jenis investasi tersebut memberikan sinyal tentang pertumbuhan pendapatan perusahaan yang diharapkan di masa yang akan datang dan mampu meningkatkan nilai pasar perusahaan.

\subsubsection{Pengaruh Keputusan Pendanaan Terhadap Nilai Perusahaan}

Hasil penelitian pada tabel 4. menunjukan signifikan 0,05 dengan nilai signifikan sebesar 0,057. Maka dapat disimpukan bahwa DER tidak berpengaruh terhadap BPV sehingga hipotesis kedua ditolak.

Hal ini dapat disebabkan karena hutang merupakan salah satu sumber pembiayaan yang memiliki tingkat risiko yang tinggi. Risiko tersebut berhubunga dengan risiko pembayaran bunga yang umumnya tidak dapat ditutupi perusahaan. Hutang yang tinggi akan berdampak pada kurang kepercayaan publik terhadap perusahaan. Dengan asumsi apabila perusahaan menghasilkan laba, 
prioritas utama adalah membayar hutang dari pada mensejahterakan kemakmuran pemegang saham, sehingga nilai perusahaan akan menurun.

Disisi lain penambahan hutang akan meningkatkan tingkat risiko atas arus pendapatan perusahaan. Semakin besar hutang, semakin besar pula kemungkinan terjadinya perusahaan tidak mampu membayar kewajiban tetap berupa bunga dan pokoknya. Risiko kebangkrutan akan semakin tinggi karena bunga akan meningkat lebih tinggi daripada penghematan pajak. Oleh karena itu, perusahaan harus sangat hati-hati dalam menentukan kebijakan hutangnya karena peningkatan penggunaan hutang akan menurunkan nilai perusahaan.

Hasil penelitian ini konsisten dengan penelitian yang dilakukan oleh Yunitasari (2014) menyatakan bahwa manajer akan berusaha meningkatkan tingkat hutang sampai pada suatu titik dimana nilai perlindungan pajak bunga tambahan benar- benar terimbangi oleh tambahan biaya masalah keuangan. Artinya disini penggunaan hutang akan meningkatkan nilai perusahaan hanya sampai pada suatu titik optimal. Setelah titik tersebut penggunaan hutang justru dapat menurunkan nilai perusahaan karena kenaikan keuntungan dari penggunaan hutang tidak sebanding dengan biaya finansial atau kewajiban biaya bunga dari hutang.

\subsubsection{Pengaruh Kebijakan Deviden Terhadap Nilai Perusahaan}

Berdasarkan hasil penelitian dilakukan menjukan bahwa signifikan 0,05 dengan nilai sebesar 0,794 sehingga dapat dikatakan bahwa DPR tidak berpengaruh terhadap BPV maka dapat dikatakan hipotesis ketiga ditolak

Hasil variabel kebijakan dividen tidak dapat berpengaruh secara signifikan terhadap nilai perusahaan mungkin disebabkan karena investor tidak membutuhkan dividen untuk mengkonversi saham mereka menjadi uang tunai, mereka tidak akan membayar harga yang lebih tinggi untuk perusahaan dengan pembayaran dividen yang lebih tinggi. Dengan kata lain, kebijakan dividen tidak akan berdampak pada nilai perusahaan. Hal ini sesuai dengan teori menurut Brealey, Myers dan Marcus (2008:54) bahwa, "Karena investor tidak membutuhkan dividen untuk mengkonversi saham mereka menjadi uang tunai, mereka tidak akan membayar harga yang lebih tinggi untuk perusahaan dengan pembayaran dividen yang lebih tinggi. Dengan kata lain, kebijakan dividen tidak akan berdampak pada nilai perusahaan."

Penelitian ini mendukung penelitian Afzal Arie (2012) dan Endarma ( 2014) yang menyatakan kebijakan deviden tidak berpengaruh terhadap nilai perusahaan. Penelitian ini mendukung penelitian Yogi (2014) yang menyatakan bahwa kebijakan deviden adalah kebijakan perusahaan yang berhubungan dengan presentase laba bersih perusahaan yang dibagikan kepada pemilik saham di dalam perusahaan untuk menentukan deviden yang akan dibagikan kepada pemilik saham bukan menjadi faktor utama perubahan nilai perusahaan, karena sesuai dengan teory irrelevansi deviden yang menyatakan tidak ada kebijakan deviden yang optimal. Investor dan pihak luar cenderung tidak tertarik untuk mengetahui seberapa besar deviden yang dibagikan, karena mereka berpedoman bahwa tidak ada kebijakan deviden yang optimal.

\section{PENUTUP}

\subsection{Kesimpulan}

Penelitiaan ini bertujuan untuk menganalisis pengaruh Keputusan Investasi, Keputusan Pendanaan dan Kebijakan Dividen terhadap Nilai Perusahaan pada seluruh perusahaan yang terdaftar di Bursa Efek Indonesia selama periode 2014-2016: 
1. Keputusan investasi yang diukur menggunakan Price Earning Ratio berpengaruh positif dan signifikan terhadap nilai perusahaan dengan tingkat signifikan

2. Keputusan pendanaan berpengaruh terhadap nilai perusahaan. Tingkat signifikansi sebesar $0,057>0,05$ yang berarti dapat dikatakan bahwa keputusaan pendanaan tidak berpengaruh terhadap nilai perusahaan

3. Kebijakan dividen berpengaruh terhadap nilai perusahaan yang dimna tingkat signifikansi sebesar 0,794 >0,05 sehingga keputusan kebijakan dividen tidak berpengaruh terhadap nilai perusahaan

\subsection{Keterbatasan Penelitian}

Penelitiaan ini masih mempunyai beberapa keterbatasan antara lain

1. Penelitiaan ini hanya menguji beberpa factor yang mempengaruhi nilai perusahaan yaitu keputusan investasi,keputusaan pendanaan dan kebijakan dividen

2. Penelitiaan ini hanya mengambil periode penelitian tiga tahun yaitu $2014-2016$

\subsection{Saran}

Berdasarkan pada kesimpulan dan keterbatasan dalam penelitian ini, maka dapat disampaikan beberapa saran sebagai berikut

1. Bagi Investor

Diharapkan bahwa hasil penelitian ini dapat memberikan informasi mengenai factor-faktor yang dapat mempengaruhi nilai perusahaan yaitu keputusan investasi

2. Bagi Manajer Keuangan

Manajer keuangan sebaiknya dapat mempertimbangkan variabel yang secara simultan berpengaruh positif terhadap nilai perusahaan

3. Bagi Peneliti Selanjutnya

a) Memperbanyak tahun pengamatan untuk mendapatkan hasil yang baik

b) Penelitian selanjutnya diharapakan menabah variabel seperti profitabilias perusahaan ataupun menambah variabel eksternal seperti inflasi, nilai kurs, dan lain-lain. 


\section{DAFTAR PUSTAKA}

Afzal Arie, R. A. (2012). Pengaruh keputusan investasi, keputusan pendanaan, dan kebijakan deviden terhadap nilai perusahaan, 1(1998), 1-9.

Andriani, L., Kardinal, \& Wijaya, T. (2014). Pengaruh keputusan investasi, keputusan pendanaan, dan kebijakan dividen terhadap nilai perusahaan, (3).

Brigham, E. F., dan J. F. H. . (2001). Manajemen Keuangan. Edisi Bahasa Indonesia. Jakarta:Erlangga.

Endarmawan, Y. (2014). Pengaruh Keputusan Investasi, Keputusan Pendanaan dan Kebijakan Deviden Terhadap Nilai Perusahaan. Artikel Ilmiah, Universitas Jember.

Fama, E. F. (1978). The Effect of a Firm's Investment and Financing Decision on the Welfare of its Security Holders. American Economic, Review 68: 272-

Hasnawati, S. (2005). DAMPAK SET PELUANG INVESTASI TERHADAP, 117-126.

Ningsih, P. P., \& Indarti, I. (2009). Dan Kebijakan Dividen Terhadap Nilai Perusahaan ( Studi Kasus Pada Perusahaan Manufaktur Yang Terdaftar Di Bursa Efek Indonesia Periode 2007-2009) The Influence of Investment Decision, Financing Decision, And Dividend Policy on Firm Value ( Case Study. Journal of Financial and Banking, 1(1), 1-23.

Purnamasari, L., Kurniawati, S. L., \& Silvi, M. (2009). Interdependensi Antara Keputusan Investasi,Keputusan Pendanaan dan Keputusan Dividen. Jurnal Keuangan Dan Perbankan, 13(1), 106-119.

Setiawan, D., \& Hartono, J. (2003). pengujian efesiensi pasar bentuk setengah kuat secara keputusan,analisis keputusan dividen meningkat. Riset Akutansi Indonesia 6, 131-144.

Sujoko, \& soebiantoro ugy. (2007). pengaruh struktur kepemilikan leverange,faktor ekstern terhadap nilai perusahaan (studi empiris perusahaan manufaktur dan non maufaktur di bursa efek jakarta). Manajemen Dan Kewirausahaan, 9 no 1 mar, 41-48.

Wijaya, L. R. P. dan B. A. W. (2010). Pengaruh Keputusan Investasi, Keputusan Pendanaan dan Kebijakan Deviden terhadap Nilai Perusahaan. Simposium Nasional Akuntansi XIII. Purwokerto.

Yunitasari, D. (2014). Pengaruh Keputusan Investasi, Keputusan Pendanaan, Kebijakan Dividen, dan Tingkat Suku Bunga terhadap Nilai Perusahaan pada Sektor Property dan Real Estate yang Terdaftar di Bursa Efek Indonesia. Skripsi. Sekolah Tinggi Ilmu Ekonomi Indonesia (STIESIA). Surabaya. 